\title{
Short Sales Constraints and Price Adjustment to
}

\section{Earnings Announcements}

\author{
Min Bai*, Yafeng Qin, and Alireza Tourani-Rad ${ }^{1}$
}

(This Version, October 2013)

\begin{abstract}
This study looks at how short sales constraints affect the stock price adjustment to the release of public information in the Hong Kong Stock Exchange for a sample of 4,757 firm-event observations over the period 1994-2011. Using a unique feature of this market that allows us to directly investigate the impact of the imposition of short sales restriction, we find following results. First, nonshortable stocks react more strongly to negative information than shortable stocks. Second, nonshortable stocks are overpriced before the negative earnings announcement. Hence, part of the strong market reaction of nonshortable stocks on announcement day could be due to the correction of such overpricing. Third, prices of nonshortable stocks reverse following the announcement of negative information, suggesting that investors overreact to the negative information on the announcement day. Fourth, it takes longer time for the prices of nonshortable stocks to fully adjust to the negative earnings information. On the whole, our results are supportive of the stream of research that finds the imposition of short sales restrictions reduce the efficiency of stock markets.
\end{abstract}

JEL Classifications: G14 G18

Keywords: Short Sales Constraints, Earnings Announcement, Post-Event Analysis

\footnotetext{
${ }^{1}$ Min Bai and Alireza Tourani-Rad are from Auckland University of Technology and Yafeng Qin is from Massey University.

* Corresponding author: Min Bai, min.bai@aut.ac.nz.
} 


\section{Introduction}

Generally, during financial market crisis many regulators around the world attempt to constrain short selling activities. Regulators, due to market pressure looking for an escape route or their genuine belief, argue that short sales destabilize the markets and lead prices to deviate far away from their fundamental values. Regulators contend that through banning short selling activities, they could prevent sudden and significant drops in stock markets. Beber and Pagano (2013) report that among the 30 markets in their sample, 21 imposed shortselling ban during the 2008-2009 crisis, either on the whole stock markets or some specific sectors.

However, the extant research questions the effectiveness of such drastic practices. Diamond and Verrecchia (1987) explore the impact of short sales constraints on the speed of price adjustment to private information. They show that when short sales are constrained, individual stock prices adjust slowly to common factor information, particularly to negative information. And when private information becomes public, price adjustments are larger in magnitude. Abreu and Brunnermeier (2002, 2003), Scheinkman and Xiong (2003) show that short sales constraints can lead to formation of bubbles and excessive volatility in markets. Hong and Stein (2003), using heterogeneous agent model, further show that if investors are constrained from short selling, their accumulated unrevealed negative information will aggravate a market decline, leading to a crash. These findings show that instead of stabilizing the markets as regulators hope for, short sales constraints could actually destabilize the markets and have an adverse effect on efficiency of stock prices.

Bernardo and Welch (2004), in contrast, develop a theoretical model showing that it is the fear of financial crisis, instead of a real liquidity shock, that causes a financial crisis. One implication of their model is that some market constraints, such as imposing short sales 
constraints, can hinder some market participants from front-running other investors and thus can effectively prevent financial crisis. Their conjecture is consistent with Allen and Gale (1991) who show that short selling can destabilize the economy.

Besides the theoretical debate on the effect of short sales constraints on markets, there are also many empirical studies. Jones and Lamont (2002), and Chang, Cheng and Yu (2007), using U.S data and Hong Kong data, respectively, find that stocks that are expensive to short, or with short sales constraints, are overpriced. They also document higher volatility when short sales are allowed. These findings are consistent with Miller (1977)'s prediction, suggesting a market stabilizing function for short-sales constraints. Asquith and Meulbroek (1995), Aitken et al. (1998) and Danielsen and Sorescu (2001), all find that the introduction of short sales is associated with negative future returns, indicating that negative information is incorporated into prices more slowly when short sales constrains are in place. Similar findings are found in studies by Fung and Draper (1999), Bris, et al. (2007), Boehmer, Jones and Zhang (2008), Boehmer and Wu (2007), and Chen and Rhee (2010).

Our study adds to the literature by empirically looking at how stocks with/without short sales constraints react to the public information. The current study is mainly motivated by Diamond and Verrecchia (1987) who develop a rational expectations model where investors take into account the short sales constraints when making their investment decisions. According to their model, as investors with private negative information are prevented from short selling, it takes longer time for information to be incorporated into prices, especially negative information. Hence, when the information is made public, stocks with short-sales constraints will react more strongly to the information than stocks without such constraints. Hence their model has two empirically testable predictions: (1) Stocks with short-sales constraints react more strongly to public information than stocks without such constraints; (2) 
Stocks with short-sales constraints react to public information more slowly than stocks without such constraints, particularly to negative information.

There has been some research that empirically tests this model, using the introduction of exchange traded options as a proxy for the possibility of short selling (Jennings and Starks, 1986; Skinner, 1990), or the loan prices in the lending market to proxy for the cost of short selling (Reed, 2007). The advantage of our study is the use of a direct measure of short sales constraints-our sample stocks are deliberately separated into two groups: one group of stocks can be freely sold short, while the other is strictly forbidden to be sold short, though they are traded in the same stock market, namely Hong Kong Stock Exchange (HKSE, henceforth). This market provides an ideal setting to conduct our research where only stocks that meet certain requirements are allowed to be sold short. The list of designated stocks that can be sold short is revised on a quarterly basis, and stocks that become newly eligible are added to the list while stocks that become no longer eligible are removed from the list. The presence of such a practice enables us to compare the reaction of stocks with/without shortsales constraints to the same type of information. In particular, we use the event study methodology to examine if stocks that are allowed to be sold short react differently than stocks that are not allowed to be sold short to earnings announcements. Moreover, changes in short-sales constraints for stocks take place at different times, which helps to reduce the possibility that our cross-sectional analysis will suffer from potential contemporaneous changes in other market-wide factors (Bessembinder, 2000, Chang, Cheng and Yu, 2007). The public information proxy we use is the earnings announcements.

Consistent with Diamond and Verrecchia (1987)'s predictions, we find that on the announcement day prices change more significantly for stocks with short-sales constraints than stocks without constraints, for both positive and negative information. On average, abnormal returns of shortable stocks amounts to $-5.57 \%$ on the announcement of negative 
information, while those of non-shortable stocks is $-8.10 \%$. On the announcement of positive earnings news, shortable and non-shortable stocks have average abnormal returns of $7.83 \%$ and $12.60 \%$, respectively.

In order to gain more insight into the reaction of shortable versus nonshortable stocks, we further look at the price behaviour of stocks around the earnings announcements, i.e., 10 days before and 60 days after the announcements. We find that during the 10 days before the announcement of the negative earnings news, prices of nonshortable stocks increase substantially more than those of shortable stocks $(2.32 \%$ vs. $0.79 \%)$. Such phenomenon is consistent with Miller's overpricing theory (Miller, 1977). Before the information is publicly available, there is heterogeneous expectation on the information. But due to the short sales constraints, while optimistic investors are able to incorporate their future expectation of firm performance into prices by simply buying the stocks, many pessimistic investors cannot sell the stocks because they do not own them. Hence, stocks with short sales constraints are overpriced until the information is made public and part of their greater price reaction of nonshortable stocks on the announcement day is the correction of the overpricing formed previously. For the good earnings information, over the 10 days before announcements, the abnormal returns for shortable and non-shortable stocks are $-0.96 \%$ and $0.51 \%$, respectively. Although the non-shortable stocks exhibit overvaluation relative to shortable stocks again, the magnitude is much smaller compared with the scenario when bad earnings announced.

We further investigate the pricing of the stocks following the announcements to see how efficiently the prices react to public information, applying Savor's regression framework (Savor, 2012). Our results indicate that while prices of shortable stocks react efficiently to the negative information on the announcement day, prices of nonshortable stocks seem to overreact to the information, with prices reversing following the announcements. Therefore, part of the greater price reaction of nonshortable stocks on the announcement day is caused 
by investors' overreaction. Further test shows that it takes, on average, 9 days for the nonshortable stocks to fully correct the mispricing. However, when we look at good earnings announcements, both shortable and non-shortable stocks react to the information efficiently. The result confirms Diamond and Verrecchia (1987)'s prediction that short-sales constraints delay stocks' price adjustment to negative information.

Our study contributes to the debate on impact of short-sales constraints on price efficiency by explicitly examining the price behaviour around earnings announcements of both stocks with short-sales constraints and stocks without constraints. Besides providing empirical evidence to support the theoretical prediction that short-sales constraints enlarge stocks' reaction to negative public information and prolong their price adjustments, our findings suggest that the big price drops of nonshortable stocks on the announcement of negative news come from three sources: 1) convergence to new fundamentals, 2) correction of previous overpricing, and 3) overreaction to new information. Such insight adds to the literature on short sales constraints and market efficiency with important implications for regulators and market participants.

The rest of this paper proceeds as follows. Section 2 introduces the background of the Hong Kong stock market and the selection of our sample. Section 3 describes our data and methodology. Section 4 presents the empirical results and Section 5 concludes.

\section{Short Sales in HKSE and Sample Selection}

Short sales were prohibited on the Hong Kong Stock Exchange (HKSE) until January 1994 when a pilot scheme was introduced under which 17 stocks became eligible for short selling. From January 1994, the HKSE also adopted the "uptick rule", which mandated that a 
short sale could not be made below the best current ask price. The rule was repealed in March 1996, but reinstated on September 71998 following the 1997 Asian Financial Crisis. The designated list of stocks that can be sold short is revised on a quarterly basis since 1996. By December 2011, the end of our sample period, the list had been revised 104 times.

\section{[Insert Table 1 here]}

Table 1 presents the information on historical revision of the short selling list on HKSE. Columns 1 and 5 (labelled "Change Date") indicate the effective dates on which a new version of the list of designated stocks for short selling took effect. Columns 2, 6 and 10 (labelled "Addition") report the number of stocks that are newly added to the list during each revision. These stocks will be able to be sold short from the indicated effective date onwards. Columns 3, 7 and 11 (labelled "Deletion") report the number of stocks that are removed from the list during each revision. These stocks will no longer be allowed to be sold short from the effective date onwards. Columns 4, 8 and 12 (labelled "No. of on-list stocks") report the total number of stocks that can be sold short after the effective date of each revision. By December 2011, there are 1,777 additions and 1,171 deletions. A closer look at all the stocks involved during these revisions shows that some stocks have never appeared on the list, some had been added to the list but were removed from it later, and some were added to the list and have never been removed from it.

The unique feature of HKSE on short selling enables us to investigate how stocks with different short sales constraints (i.e., stocks on the list and thus can be sold short versus stocks that are not on the list and thus are constrained to be sold short) react to earnings announcements. Following Diamond and Verrecchia (1987) prediction, we investigate two types of news, good and bad, and examine how short-sales constraints affect stocks' reaction to the news. 


\section{Data and Methodology}

We obtain the earnings announcement dates through Thomson Reuters via SIRCA. Daily closing price, market capitalisation and book-to-market ratio for all Hong Kong stocks traded on the HKSE, including both shortable and non-shortable stocks, and Hang Seng Price Index are sourced from DataStream. Our sample period is from $1^{\text {st }}$ January 1994 to $31^{\text {st }}$ December 2011.

It is important to first classify the types of news. There are various ways in the literature that have been used to define the types of news (positive or negative). In this study, we follow Engelberg, Reed and Ringgenberg (2012) to identify positive and negative earnings announcements. They define a negative (positive) news event as one where a firm's announcement day return is in the bottom (top) quintile of all returns on a given day, and a neutral news event when a firm's announcement day return is in neither the top, nor the bottom quintile.

We use the standard event study in examining the price reaction of stocks to negative earnings announcements. In comparison with the cross-sectional analysis adopted by most empirical studies on short sale constraint, where it is hard to control for many exogenous and endogenous factors, event study is relatively free of this problem. The abnormal return $(A R)$ and cumulative abnormal returns $(C A R)$ are defined as:

$$
\begin{aligned}
& A R_{i}(t)=R_{i t}-\mathrm{R}_{f}-\beta_{i} *\left(R_{m t}-R_{f}\right) \\
& C A R_{i\left(t_{1}, t_{2}\right)}=\sum_{t=t_{1}}^{t_{2}}\left[R_{i t}-\mathrm{R}_{f}-\beta_{i} *\left(R_{m t}-R_{f}\right)\right]
\end{aligned}
$$

where $A R_{i}(t)$ indicates the abnormal return of stock $i$ at event day $t$, with event day 0 defined as announcement day. $C A R_{i\left(t_{1}, t_{2}\right)}$ represents the cumulative abnormal return between 
$t_{1}$ and $t_{2}$ in different event windows, $\beta_{i}$ represent the estimated slope coefficient for the stock $i$ based on the stock's historical return series from day -31 to day $-280, R_{f}$ and $R_{m}$ are the risk free rate (the three-month Hong Kong interbank offered rate) and the Hong Kong stock exchange market return calculated based on Hang Seng index.

For each group of stocks (shortable and nonshortable), we rank all the negative (positive) $A R_{0}$, i.e., the abnormal returns on the announcement day, and select the stocks whose $A R_{0} \mathrm{~s}$ fall in the bottom (top) quintile as our sample. We then compute the average $A R_{0}$ of shortable and nonshortable sample and compare their difference. According to Diamond and Verrecchia (1987), the absolute value of average $A R_{0}$ should be higher for nonshortable stocks than shortable stocks.

To gain more insights into the price reaction of different types of stocks to the earnings announcements, we look at the CARs of various event windows of the two types of stocks around the announcements. In particular, we apply regression framework proposed by Savor (2012) to investigate the post earnings announcement pricing of the stocks. In so doing, we regress the post earnings $C A R s$ of various windows on the event day abnormal return $A R_{0}$, to see how efficiently the prices react to the information on the event day:

$$
C A R_{m, n}=\alpha+\beta_{i} * A R_{0}+\gamma^{\prime} X+\mu
$$

Where $C A R_{m, n}$ is the cumulative abnormal return over a period starting from day $m$ to day $\mathrm{n}$ after the event date, and $A R_{0}$ is the event day abnormal return. $X$ are a number of control variables including log size $(\log (M V))$, log book-market-ratio $(\log (B M))$ and trading volume (VOL). We use the WLS regression to estimate the parameters, where weights are set to be equal cross-sectional. $T$-statistics are calculated using clustered standard errors. Positive $\beta_{i}$ indicates that there is a return continuation following the announcements, suggesting that investors underreact to the information on the event day. While negative $\beta_{i}$ means that prices 
reverse following the announcement, suggesting that investors overreact to the information. Also, by varying event window $(m, n)$, we can find out how long it will take for the prices to fully incorporate all the information.

\section{Empirical Results and Analysis}

We first compare the event day abnormal returns of nonshortable stocks with those of shortable stocks. The results are presented in Table 2. We report the abnormal returns of both types of stocks from day -10 to day 10 , and for both types of earnings announcements. We observe that, consistent with Diamond and Verrecchia (1987), prices drop (increase) more significantly for nonshortable stocks than for shortable stocks on announcement of bad (good) news. On the day when negative earnings information is released, prices of shortable stocks on average drop by $5.57 \%$ (median of $4.71 \%$ ), while those of nonshortable stocks drop by $8.10 \%$ (median of $6.40 \%$ ), which is $45 \%$ higher than the shortable stocks. When positive earnings information is released, prices of shortable stocks on average increase by $7.83 \%$ (with a median of $6.90 \%$ ), while those of nonshortable stocks increase by $12.60 \%$ (median of 9.56\%). Second, for the bad news announcements, both types of stocks on average exhibit positive abnormal returns around one week before the announcement. But when we compare the magnitude of the positive returns, we can see that the absolute values of abnormal returns from nonshortable stocks are again much higher than those from shortable stocks. Such finding is consistent with Miller (1977) overpricing prediction that before private information is made public, there is a divergent opinion among investors regarding the information. When short sales are not allowed, only optimistic opinions are incorporated into prices, causing the assets to be overvalued. That is why we see higher positive returns before earnings announcement from nonshortable stocks than from nonshortable stocks. Similar pattern also 
appears for the good news announcements. While shortable stocks have negative abnormal returns before the announcements, nonshortable stocks show significant positive abnormal returns during the same period of time, resulting in a more significant difference between shortable and nonshortable stocks.

[Insert Table 2 here]

The second point above is further confirmed in Table 3 where we present the CARs with various event windows for both types of stocks, and test their differences. We can see that from day -10 to day -2 before the announcements of negative earnings news, shortable stocks increase in prices by $0.79 \%$, while nonshortable stocks increase in prices by $2.32 \%$, which is three times as high as shortable stocks. The difference is highly significant. And such pattern is vividly shown in Figure 1 . But for CAR $(-10,-2)$ of stocks before good earnings announcements, it is $-0.96 \%$ for shortable stocks and $0.51 \%$ for non-shortable stocks. And such difference is, again, probably caused by overpricing of nonshortable stocks.

[Insert Table 3 here]

[Insert Figure 1 here]

We next turn to test the efficiency of the price reaction to the earnings announcements by both types of stocks. In so doing, we apply Savor (2012) model and run cross-sectional regression of the post-event CARs with various event windows on the event day abnormal return $\mathrm{AR}_{0}$. If the regression coefficient is positive, it means that there is price continuation following the event, i.e., after the negative (positive) earnings announcement dates, prices continue to drop (rise). Hence, it suggests that investors underreact to the earnings announcement on the event days. However, if the regression coefficient is negative, it means that prices reverse after the event days, which is an evidence indicating that investors 
overreact to the earnings announcements. Our regression results on shortable and nonshortable stocks are reported in Table 4.

[Insert Table 4 here]

In Table 4, we reports the regression results on shortable and nonshortable stocks with good and bad earnings announcements in Panels A, B, C and D, respectively. The dependent variables are $C A R s$ with various specification of the event windows, namely $(1,1),(1,5)$, $(1,10),(1,20),(1,30),(1,40),(1,50)$ and $(1,60)$. In Panel A (reaction of shortable stocks to negative news), $\mathrm{B}$ (reaction of shortable stocks to positive news), and D (reaction of nonshortable stocks to positive news), coefficients on $A R_{O}$ under all the specifications are statistically indifferent from 0 , suggesting when good earnings announcements are made public, all stocks, either shortable or nonshortable, incorporate the information into prices quickly and efficiently on the announcement days. And when bad earnings announcements are publicized, shortable stocks also react quickly and efficiently to the information. Panel C, however, shows that coefficients on $\mathrm{AR}_{0}$ when dependent variables are $C A R(1,1), C A R(1,5)$ and $C A R(1,10)$ are negative and statistically significant at $10 \%$ level. It means that prices of nonshortable stocks reverse after the bad earnings announcements, suggesting an overreaction of nonshortable stocks toward negative public information on the announcement days. The coefficients on $A R_{0}$ of other specifications are insignificant, implying that the overreaction gets corrected within 10 days following the announcements.

In order to investigate the speed of price adjustment of nonshortable stocks after the earnings announcement, we further refine our test by changing the event windows of our regressor CARs. As results reported in Panel $\mathrm{C}$ of Table 4, indicate that prices of nonshortable stocks reverse within about 10 days following the announcement day. We further define our 
dependent variables as $C A R(1, \mathrm{n})$ where $n$ changes from 1 to 15 and reports our results in Table 5.

We can see that while all coefficients on $A R_{0}$ are negative, they become statistically insignificant after day 9. Before that day, all the coefficients are negative and statistically significant. For example, when $C A R(1,1)$ is regressed on $A R_{0}$, the coefficient is -0.1477 , with t-statistics of -2.62 . This finding implies that following the significant drops on the event day, prices of nonshortable stocks reverses on the next day. And the higher the price drops on day 0 , the higher the price rises on day 1 . Such price reversal continues until day 9 , though the statistical significance gradually declines. After day 9, the $C A R s$ are no longer related to $A R_{0}$. Hence, it takes about 9 days for the information to be correctly and fully incorporated into prices of nonshortable stocks.

\section{Conclusions}

This study looks at how short sales constraints impact the price adjustment to information. In particular, we look at how stocks with short sales constraints react differently to earnings announcements from stocks without short sales constraints. Our empirical tests show that, consistent with the prediction from a theoretical framework in Diamond and Verrecchia (1987), nonshortable stocks react more strongly to the negative information than shortable stocks. We further find that nonshortable stocks are more overpriced before the announcements of negative earnings news. Hence, part of the strong reaction of prices of nonshortable stocks on announcement day is the correction for such overpricing. Next, we report that prices of nonshortable stocks reverse following the announcement of negative information, suggesting that investors may overreact to negative information on the announcement day. But such evidence is absent from shortable stocks, showing that stocks 
without short sales constraints react to information quickly and accurately. Lastly, our test indicates that it takes about 9 days for the prices of nonshortable stocks to fully adjust to the negative earnings information. Such findings contribute to a better understanding of effect of short-sales constraints on market informational efficiencies, and will have important implication to regulators, practitioners and academia theorists. 


\section{References}

Aitken, M. J., Frino, A., McCorry, M. S., \& Swan, P. L. (1998). Short sales are almost instantaneously bad news: Evidence from the Australian Stock Exchange. The Journal of Finance, 53(6), 2205-2223.

Beber, A., \& Pagano, M. (2013). Short-Selling Bans Around the World: Evidence from the 2007-09 Crisis.The Journal of Finance, 68(1), 343-381.

Berkman, H., Dimitrov, V., Jain, P. C., Koch, P. D., \& Tice, S. (2009). Sell on the news: Differences of opinion, short-sales constraints, and returns around earnings announcements. Journal of Financial Economics, 92(3), 376-399.

Berkman, H., \& McKenzie, M. D. (2012). Earnings announcements: Good news for institutional investors and short sellers. The Financial Review, 47(1), 91-113.

Biais, B., Bisière, C., \& Décamps, J.-P. (2002). Short sales constraints, liquidity and price discovery: An empirical analysis on the Paris Bourse. European Financial Management, 5(3), 395-410.

Boehmer, E., Jones, C. M., \& Zhang, X. (2008). Which shorts are informed? The Journal of Finance, 63(2), 491-527.

Boehmer, E., \& Wu, J. (2008). Short selling and the informational efficiency of prices. Texas A\&M University, unpublished manuscript.

Bris, A., Goetzmann, W. N., \& Zhu, N. (2007). Efficiency and the bear: Short sales and markets around the world. The Journal of Finance, 62(3), 1029-1079. 
Chang, E. C., Cheng, J. W., \& Yu, Y. (2007). Short-sales constraints and price discovery: Evidence from the Hong Kong market. The Journal of Finance, 62(5), 2097-2121.

Chen, C. X., \& Rhee, S. G. (2010). Short sales and speed of price adjustment: Evidence from the Hong Kong stock market. Journal of Banking \& Finance, 34, 471-483.

Christophe, S. E., Ferri, M. G., \& Angel, J. J. (2004). Short-selling prior to earnings announcements. The Journal of Finance, 59(4), 1845-1876.

Daske, H., Richardson, S. A., \& Tuna, İ. (2005). Do short sale transactions precede bad news events? Working paper, University of Pennsylvania.

Diamond, D. W., \& Verrecchia, R. E. (1987). Constraints on short-selling and asset price adjustment to private information. Journal of Financial Economics, 18(2), 277-311.

Diether, K. B., Lee, K.-H., \& Werne, I. M. (2009). Short-sale strategies and return predictability. Review of Financial Studies, 22, 575-607.

Engelberg, J. E., Reed, A. V., \& Ringgenberg, M. C. (2012). How are shorts informed? Journal of Financial Economics, 105(2), 260-278.

Figlewski, S. (1981). The information effects of restrictions on short sales: Some empircial evidence. Journal of Financial and Quantitative Analysis, 16(4), 463-476.

Fung, J., \& Draper, P. (1999). Mispricing of index futures contracts and short sales constraints. Journal of Futures Market, 19, 695-715.

Geczy, D. C., Musto, d. K., \& Reed, A. V. (2002). Stocks are special too: An analysis of the equity lending market. Journal of Financial Economics, 66, 214-269. 
Griffin, J. M., Shu, T., \& Topaloglu, S. (2008). How informed are the smart guys? Evidence from short-term institutional trading prior to major events. Unpublished Working Paper.

Hong, H., Kubik, J. D., \& Fishman, T. (2012). Do arbitrageur samplify economic shocks? Journal of Financial Economics, 103(3), 454-470.

Jones, C. M., \& Lamont, O. A. (2002). Short-sale constraints and stock returns. Journal of Financial Economics, 66(2-3), 207-239.

Lasser, D. J., Wang, X., \& Zhang, Y. (2010). The effect of short selling on market reactions to earnings announcements. Contemporary Accounting Research, 27(2), 609-638.

Li, L., \& Fleisher, B. M. (2004). Heterogeneous expectations and stock prices in segmented markets: Application to Chinese firms. The Quarterly Review of Economics and Finance, 44(4), 521-538.

Miller, E. M. (1977). Risk, uncertainty, and divergence of opinion. The Journal of Finance, $32,1151-1168$.

Poitras, G. (2002). Short sales restrictions, dilution and the pricing of rights issues on the Singapore Stock Exchange. Pacific-Basin Finance Journal, 10(2), 141-162.

Reed, A. V. (2007). Costly short selling and stock price adjustment to earnings announcements. Unpublished working paper.

Zheng, L. (2009). Short sales and post earnings announcement drift. Available at SSRN. 
Figure 1: Cumulative Abnormal Returns of Shortable Stocks and Non-Shortable Stocks (Bad News)

This figure presents the cumulative average daily abnormal returns for shortable stocks (SS) and non-shortable stocks (NSS) over a 21 day period around the negative and positive earnings announcements.
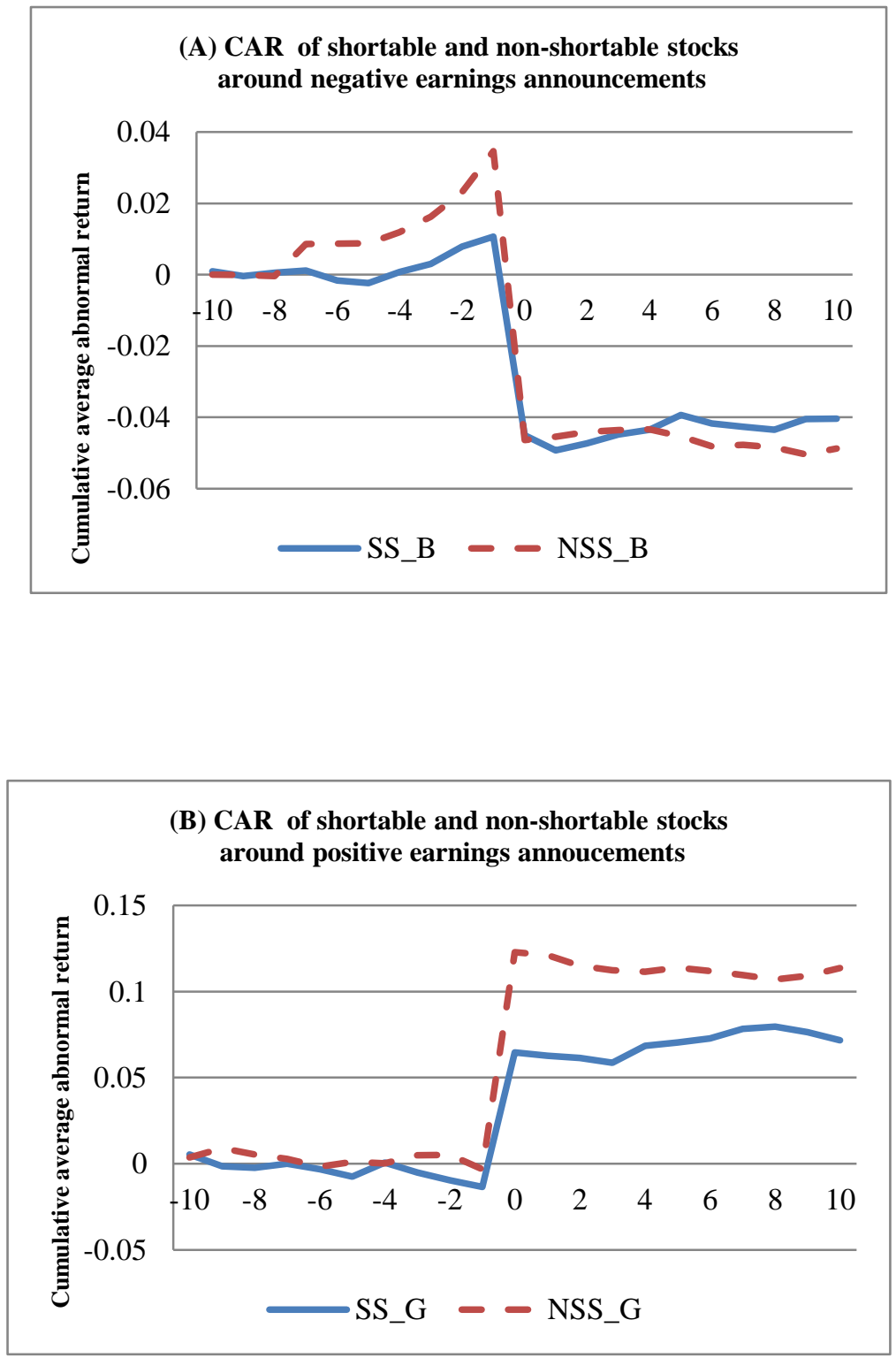
Table 1: Changes in the Official Short-Selling List

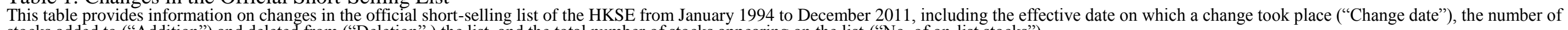

\begin{tabular}{|c|c|c|c|c|c|c|c|c|c|c|c|}
\hline Change Date & Addition & Deletion & No. of on-list stocks & Change Date & Addition & Deletion & No. of on-list stocks & Change Date & Addition & Deletion & No. of on-list stocks \\
\hline $3 / 3 / 01 / 1994$ & 17 & 0 & 17 & $1717 / 05 / 2005$ & 37 & 9 & 264 & $3 / 3 / 06 / 2008$ & 5 & 0 & 545 \\
\hline 25/03/1996 & 96 & 0 & 113 & $8 / 07 / 2005$ & 1 & 0 & 265 & $7 / 08 / 2008$ & 10 & 51 & 504 \\
\hline $1 / 05 / 1997$ & 129 & 1 & 241 & $15 / 07 / 2005$ & 1 & 0 & 266 & $14 / 11 / 2008$ & 6 & 144 & 366 \\
\hline $12 / 01 / 1998$ & 69 & 0 & 310 & $15 / 08 / 2005$ & 14 & 12 & 268 & $12 / 02 / 2009$ & 25 & 27 & 364 \\
\hline 16/03/1998 & 15 & 0 & 325 & $5 / 09 / 2005$ & 1 & 0 & 269 & $14 / 05 / 2009$ & 13 & 22 & 355 \\
\hline $9 / 11 / 1998$ & 19 & 149 & 195 & $28 / 10 / 2005$ & 1 & 0 & 270 & $10 / 07 / 2009$ & 1 & 0 & 356 \\
\hline $1 / 03 / 1999$ & 7 & 7 & 195 & $18 / 11 / 2005$ & 11 & 7 & 274 & $5 / 08 / 2009$ & 49 & 16 & 389 \\
\hline 20/09/1999 & 3 & 17 & 181 & $20 / 02 / 2006$ & 10 & 8 & 276 & $5 / 11 / 2009$ & 58 & 11 & 436 \\
\hline $12 / 11 / 1999$ & 1 & 0 & 182 & $1 / 03 / 2006$ & 2 & 0 & 278 & $18 / 11 / 2009$ & 1 & 0 & 437 \\
\hline $28 / 02 / 2000$ & 24 & 12 & 194 & $29 / 05 / 2006$ & 23 & 17 & 284 & $3 / 12 / 2009$ & 1 & 0 & 438 \\
\hline $31 / 05 / 2000$ & 7 & 0 & 201 & $2 / 06 / 2006$ & 1 & 0 & 285 & $15 / 12 / 2009$ & 1 & 0 & 439 \\
\hline $28 / 08 / 2000$ & 32 & 16 & 217 & $2 / 06 / 2006$ & 1 & 0 & 286 & $24 / 12 / 2009$ & 1 & 0 & 440 \\
\hline $12 / 02 / 2001$ & 15 & 11 & 221 & $25 / 08 / 2006$ & 38 & 10 & 314 & $1 / 02 / 2010$ & 65 & 8 & 497 \\
\hline $14 / 05 / 2001$ & 6 & 0 & 227 & $1 / 09 / 2006$ & 1 & 0 & 315 & $1 / 03 / 2010$ & 1 & 0 & 498 \\
\hline $20 / 08 / 2001$ & 9 & 11 & 225 & $23 / 10 / 2006$ & 1 & 0 & 316 & $10 / 03 / 2010$ & 1 & 0 & 499 \\
\hline $3 / 12 / 2001$ & 17 & 85 & 157 & $27 / 10 / 2006$ & 1 & 0 & 317 & $25 / 03 / 2010$ & 1 & 0 & 500 \\
\hline $25 / 02 / 2002$ & 7 & 14 & 150 & $1 / 12 / 2006$ & 55 & 9 & 363 & $10 / 05 / 2010$ & 59 & 12 & 547 \\
\hline $21 / 05 / 2002$ & 11 & 6 & 155 & $5 / 03 / 2007$ & 30 & 24 & 369 & $16 / 07 / 2010$ & 1 & 0 & 548 \\
\hline $29 / 07 / 2002$ & 24 & 5 & 174 & $14 / 03 / 2007$ & 1 & 0 & 370 & $4 / 08 / 2010$ & 40 & 19 & 569 \\
\hline $29 / 11 / 2002$ & 6 & 15 & 165 & $19 / 04 / 2007$ & 5 & 0 & 375 & $30 / 08 / 2010$ & 1 & 0 & 570 \\
\hline $27 / 01 / 2003$ & 5 & 7 & 163 & $26 / 04 / 2007$ & 4 & 0 & 379 & $29 / 10 / 2010$ & 47 & 18 & 599 \\
\hline $19 / 05 / 2003$ & 18 & 7 & 174 & $21 / 05 / 2007$ & 29 & 14 & 394 & $15 / 11 / 2010$ & 1 & 0 & 600 \\
\hline $21 / 07 / 2003$ & 1 & 16 & 159 & $21 / 05 / 2007$ & 1 & 0 & 395 & $22 / 11 / 2010$ & 2 & 0 & 602 \\
\hline 4/08/2003 & 0 & 1 & 158 & $29 / 05 / 2007$ & 1 & 0 & 396 & $20 / 12 / 2010$ & 1 & 0 & 603 \\
\hline $3 / 11 / 2003$ & 36 & 5 & 189 & 4/07/2007 & 1 & 0 & 397 & $30 / 12 / 2010$ & 1 & 0 & 604 \\
\hline $6 / 01 / 2004$ & 1 & 0 & 190 & $17 / 07 / 2007$ & 1 & 0 & 398 & $28 / 01 / 2011$ & 1 & 0 & 605 \\
\hline $10 / 02 / 2004$ & 29 & 3 & 216 & $13 / 08 / 2007$ & 137 & 9 & 526 & $1 / 02 / 2011$ & 1 & 0 & 606 \\
\hline $7 / 04 / 2004$ & 1 & 0 & 217 & $27 / 08 / 2007$ & 1 & 0 & 527 & $25 / 02 / 2011$ & 70 & 17 & 659 \\
\hline $27 / 04 / 2004$ & 26 & 4 & 239 & $26 / 11 / 2007$ & 64 & 23 & 568 & $24 / 05 / 2011$ & 65 & 18 & 706 \\
\hline $1 / 07 / 2004$ & 1 & 0 & 240 & $14 / 12 / 2007$ & 2 & 0 & 570 & 9/06/2011 & 1 & 0 & 707 \\
\hline $9 / 07 / 2004$ & 1 & 0 & 241 & $14 / 12 / 2007$ & 1 & 0 & 571 & $12 / 07 / 2011$ & 2 & 0 & 709 \\
\hline $2 / 08 / 2004$ & 8 & 21 & 228 & $18 / 02 / 2008$ & 33 & 41 & 563 & $12 / 08 / 2011$ & 24 & 50 & 683 \\
\hline $8 / 11 / 2004$ & 9 & 11 & 226 & $13 / 03 / 2008$ & 1 & 0 & 564 & $6 / 09 / 2011$ & 1 & 0 & 684 \\
\hline $7 / 02 / 2005$ & 15 & 7 & 234 & $13 / 05 / 2008$ & 22 & 47 & 539 & $3 / 11 / 2011$ & 18 & 97 & 605 \\
\hline $1 / 03 / 2005$ & 2 & 0 & 236 & $15 / 05 / 2008$ & 1 & 0 & 540 & $14 / 11 / 2011$ & 1 & 0 & 606 \\
\hline
\end{tabular}


Table 2: Mean Abnormal Returns around Earnings Announcements for Shortable Stocks and Non-Shortable Stocks

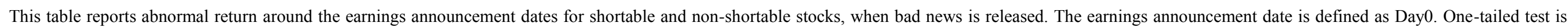
obtained by calculating the percentage of the mean of abnormal returns from the data sample. The symbols $*, * *, * *$ denote statistical significance at the $10 \%, 5 \%$ and $1 \%$ level, respectively.

\begin{tabular}{|c|c|c|c|c|c|c|c|c|c|c|c|c|}
\hline \multirow[b]{3}{*}{ Day } & \multicolumn{6}{|c|}{ Negative Earnings Announcements } & \multicolumn{6}{|c|}{ Negative Earnings Announcements } \\
\hline & \multicolumn{3}{|c|}{$\begin{array}{l}\text { Shortable Stocks } \\
\qquad(\mathrm{N}=1,489)\end{array}$} & \multicolumn{3}{|c|}{$\begin{array}{l}\text { Non-Shortable Stocks } \\
\qquad(\mathrm{N}=3,264)\end{array}$} & \multicolumn{3}{|c|}{$\begin{array}{l}\text { Shortable Stocks } \\
\qquad(\mathrm{N}=681)\end{array}$} & \multicolumn{3}{|c|}{$\begin{array}{l}\text { Non-Shortable Stocks } \\
\qquad(\mathrm{N}=1,874)\end{array}$} \\
\hline & Mean AR & Median AR & t-stats & Mean AR & Median AR & t-stats & Mean AR & Median AR & t-stats & Mean AR & Median AR & t-stats \\
\hline-10 & $0.10 \%$ & $-0.08 \%$ & 0.939 & $0.00 \%$ & $-0.02 \%$ & -0.027 & $0.53 \%$ & $-0.12 \%$ & 1.222 & $0.37 \%$ & $0.03 \%$ & $2.299^{*}$ \\
\hline-9 & $-0.14 \%$ & $-0.05 \%$ & -1.370 & $-0.01 \%$ & $0.04 \%$ & -0.079 & $-0.68 \%$ & $-0.69 \%$ & $-3.947 * * *$ & $0.53 \%$ & $0.02 \%$ & $3.280 * * *$ \\
\hline-8 & $0.10 \%$ & $-0.01 \%$ & 0.972 & $-0.03 \%$ & $-0.07 \%$ & -0.274 & $-0.07 \%$ & $-0.14 \%$ & -0.422 & $-0.37 \%$ & $-0.07 \%$ & $-2.564 * *$ \\
\hline-7 & $0.06 \%$ & $-0.11 \%$ & 0.539 & $0.90 \%$ & $0.14 \%$ & $7.330 * * *$ & $0.22 \%$ & $0.05 \%$ & 1.145 & $-0.25 \%$ & $-0.04 \%$ & $-1.805^{*}$ \\
\hline-6 & $-0.27 \%$ & $-0.45 \%$ & $-2.897 * *$ & $0.01 \%$ & $-0.01 \%$ & 0.092 & $-0.32 \%$ & $-0.10 \%$ & $-2.288^{*}$ & $-0.45 \%$ & $-0.07 \%$ & $-2.902 * *$ \\
\hline-5 & $-0.08 \%$ & $-0.10 \%$ & -0.809 & $0.01 \%$ & $-0.04 \%$ & 0.072 & $-0.43 \%$ & $-0.09 \%$ & $-2.419 * *$ & $0.27 \%$ & $0.03 \%$ & $1.883^{*}$ \\
\hline-4 & $0.31 \%$ & $0.06 \%$ & $3.190 * * *$ & $0.31 \%$ & $0.05 \%$ & $3.134 * * *$ & $0.82 \%$ & $0.13 \%$ & $3.866^{* * *}$ & $-0.09 \%$ & $-0.04 \%$ & -0.653 \\
\hline-3 & $0.23 \%$ & $-0.02 \%$ & $2.361 * *$ & $0.44 \%$ & $0.06 \%$ & $3.779 * * *$ & $-0.59 \%$ & $-0.19 \%$ & $-3.019 * *$ & $0.49 \%$ & $0.03 \%$ & $3.142 * * *$ \\
\hline-2 & $0.49 \%$ & $0.13 \%$ & $4.266 * * *$ & $0.70 \%$ & $0.08 \%$ & $6.587 * * *$ & $-0.44 \%$ & $0.01 \%$ & $-2.951 * *$ & $0.00 \%$ & $-0.16 \%$ & 0.029 \\
\hline-1 & $0.27 \%$ & $0.08 \%$ & $2.518 * *$ & $1.14 \%$ & $0.28 \%$ & $7.902 * * *$ & $-0.40 \%$ & $0.02 \%$ & $-2.383 * *$ & $-0.82 \%$ & $-0.07 \%$ & $-4.919 * * *$ \\
\hline 0 & $-5.57 \%$ & $-4.71 \%$ & $-50.226 * * *$ & $-8.10 \%$ & $-6.40 \%$ & $-78.882 * * *$ & $7.83 \%$ & $6.90 \%$ & $38.859 * * *$ & $12.60 \%$ & $9.56 \%$ & $55.119 * * *$ \\
\hline 1 & $-0.42 \%$ & $-0.46 \%$ & $-2.849 * *$ & $0.09 \%$ & $0.00 \%$ & 0.674 & $-0.21 \%$ & $0.00 \%$ & -0.844 & $-0.18 \%$ & $-0.30 \%$ & -0.797 \\
\hline 2 & $0.20 \%$ & $0.07 \%$ & 1.637 & $0.13 \%$ & $0.08 \%$ & 1.193 & $-0.13 \%$ & $-0.01 \%$ & -0.867 & $-0.62 \%$ & $-0.13 \%$ & $-4.247 * * *$ \\
\hline 3 & $0.25 \%$ & $0.01 \%$ & $2.475 * *$ & $0.05 \%$ & $-0.05 \%$ & 0.503 & $-0.26 \%$ & $-0.12 \%$ & -1.612 & $-0.26 \%$ & $-0.14 \%$ & $-2.022 *$ \\
\hline 4 & $0.14 \%$ & $-0.08 \%$ & $1.322 \$$ & $0.03 \%$ & $0.00 \%$ & 0.257 & $0.99 \%$ & $0.33 \%$ & $5.246^{* * *}$ & $-0.07 \%$ & $-0.03 \%$ & -0.453 \\
\hline 5 & $0.42 \%$ & $-0.02 \%$ & $3.964 * * *$ & $-0.20 \%$ & $-0.03 \%$ & $-1.948^{*}$ & $0.19 \%$ & $0.10 \%$ & 1.216 & $0.24 \%$ & $-0.06 \%$ & $1.645^{*}$ \\
\hline 6 & $-0.24 \%$ & $-0.29 \%$ & $-2.568 * *$ & $-0.27 \%$ & $-0.04 \%$ & $-2.905 * *$ & $0.23 \%$ & $-0.08 \%$ & 1.372 & $-0.20 \%$ & $-0.06 \%$ & -1.563 \\
\hline 7 & $-0.09 \%$ & $-0.10 \%$ & -1.125 & $0.04 \%$ & $-0.02 \%$ & 0.355 & $0.56 \%$ & $0.03 \%$ & $3.922 * * *$ & $-0.23 \%$ & $-0.09 \%$ & $-1.733^{*}$ \\
\hline 8 & $-0.08 \%$ & $-0.03 \%$ & -0.991 & $-0.07 \%$ & $-0.03 \%$ & -0.68 & $0.12 \%$ & $-0.01 \%$ & 0.786 & $-0.26 \%$ & $-0.01 \%$ & $-1.729^{*}$ \\
\hline 9 & $0.30 \%$ & $0.06 \%$ & $3.366 * * *$ & $-0.20 \%$ & $0.01 \%$ & $-1.849 *$ & $-0.33 \%$ & $-0.17 \%$ & $-2.647 * *$ & $0.23 \%$ & $0.13 \%$ & 1.317 \\
\hline 10 & $0.01 \%$ & $-0.05 \%$ & 0.116 & $0.17 \%$ & $0.06 \%$ & $1.834 *$ & $-0.47 \%$ & $-0.34 \%$ & $-3.427 * * *$ & $0.45 \%$ & $0.05 \%$ & $2.859 * *$ \\
\hline
\end{tabular}


Table 3: Cumulative Abnormal Returns (CARs) around Earnings Announcements for Shortable Stocks and Non-Shortable Stocks

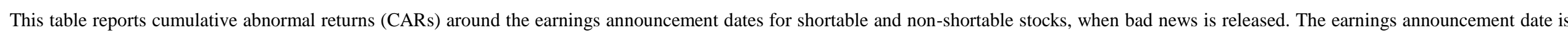

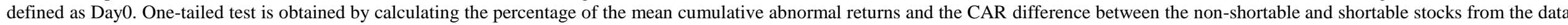
sample. The symbols *, **, *** denote statistical significance at the $10 \%, 5 \%$ and $1 \%$ level, respectively.

\begin{tabular}{|c|c|c|c|c|c|c|c|c|c|c|c|c|c|c|c|c|}
\hline & \multicolumn{8}{|c|}{ Negative Earnings Announcements } & \multicolumn{6}{|c|}{ Negative Earnings Announcements } & & \\
\hline & \multicolumn{3}{|c|}{$\begin{array}{l}\text { Shortable Stocks } \\
\qquad(\mathrm{N}=1,489)\end{array}$} & \multicolumn{3}{|c|}{$\begin{array}{c}\text { Non-Shortable Stocks } \\
(\mathrm{N}=3,264)\end{array}$} & & & \multicolumn{3}{|c|}{$\begin{array}{l}\text { Shortable Stocks } \\
\qquad(\mathrm{N}=681)\end{array}$} & \multicolumn{3}{|c|}{$\begin{array}{c}\text { Non-Shortable Stocks } \\
(\mathrm{N}=1,874)\end{array}$} & & \\
\hline Event Windows & Mean CAR & R Median CAR & t-stats & Mean CAR & Median CAR & t-stats & NSS-SS & P-value & Mean CAR & Median CAR & t-stats & Mean CAR & Median CAR & t-stats & NSS-SS & P-value \\
\hline$(-10,-2)$ & $0.79 \%$ & $0.10 \%$ & $2.430 * *$ & $2.32 \%$ & $0.76 \%$ & $8.014 * * *$ & $1.53 \%$ & 0.0005 & $-0.96 \%$ & $-0.55 \%$ & $-1.736^{*}$ & $0.51 \%$ & $-0.49 \%$ & 1.243 & $1.47 \%$ & 0.0329 \\
\hline$(-1,0)$ & $-5.30 \%$ & $-4.91 \%$ & $-33.374 * * *$ & $-6.95 \%$ & $-6.50 \%$ & $-41.522 * * *$ & $-1.65 \%$ & $<.0001$ & $7.43 \%$ & $7.12 \%$ & $29.919 * * *$ & $11.78 \%$ & $9.16 \%$ & $40.725 * * *$ & $4.35 \%$ & $<.0001$ \\
\hline$(-1,1)$ & $-5.72 \%$ & $-5.24 \%$ & $-26.178 * * *$ & $-6.86 \%$ & $-6.41 \%$ & $-33.383 * * *$ & $-1.14 \%$ & $<.0001$ & $7.22 \%$ & $7.54 \%$ & $21.737 * * *$ & $11.60 \%$ & $8.35 \%$ & $30.557 * * *$ & $4.38 \%$ & $<.0001$ \\
\hline$(-2,2)$ & $-5.03 \%$ & $-4.62 \%$ & $-17.724 * * *$ & $-6.04 \%$ & $-5.67 \%$ & $-24.074 * * *$ & $-1.01 \%$ & $<.0001$ & $6.66 \%$ & $6.22 \%$ & $16.960 * * *$ & $10.98 \%$ & $8.80 \%$ & $25.215^{* * *}$ & $4.32 \%$ & $<.0001$ \\
\hline$(-5,5)$ & $-3.77 \%$ & $-4.04 \%$ & $-10.242 * * *$ & $-5.40 \%$ & $-5.29 \%$ & $-16.156^{* * *}$ & $-1.63 \%$ & $<.0001$ & $7.37 \%$ & $7.46 \%$ & $14.377 * * *$ & $11.56 \%$ & $8.45 \%$ & $21.393 * * *$ & $4.19 \%$ & $<.0001$ \\
\hline$(0,2)$ & $-5.79 \%$ & $-5.18 \%$ & $-23.594 * * *$ & $-7.87 \%$ & $-6.86 \%$ & $-42.427 * * *$ & $-2.08 \%$ & $<.0001$ & $7.49 \%$ & $7.41 \%$ & $23.432 * * *$ & $11.80 \%$ & $8.48 \%$ & $32.596^{* * *}$ & $4.31 \%$ & $<.0001$ \\
\hline$(0,5)$ & $-4.99 \%$ & $-4.91 \%$ & $-16.937 * * *$ & $-8.00 \%$ & $-7.33 \%$ & $-33.456^{* * *}$ & $-3.01 \%$ & $<.0001$ & $8.40 \%$ & $7.84 \%$ & $19.036 * * *$ & $11.70 \%$ & $8.95 \%$ & $28.681 * * *$ & $3.30 \%$ & $<.0001$ \\
\hline$(0,10)$ & $-5.10 \%$ & $-4.69 \%$ & $-13.601 * * *$ & $-8.34 \%$ & $-7.97 \%$ & $-25.689 * * *$ & $-3.24 \%$ & $<.0001$ & $8.52 \%$ & $7.15 \%$ & $15.491 * * *$ & $11.68 \%$ & $9.76 \%$ & $23.751 * * *$ & $3.16 \%$ & $<.0001$ \\
\hline$(2,10)$ & $0.89 \%$ & $0.19 \%$ & $2.914 * * *$ & $-0.33 \%$ & $-0.69 \%$ & -1.179 & $-1.22 \%$ & $<.0001$ & $0.90 \%$ & $0.49 \%$ & $2.091 *$ & $-0.73 \%$ & $-0.87 \%$ & $-1.751^{*}$ & $-1.63 \%$ & $<.0001$ \\
\hline
\end{tabular}


Table 4: Determinants of Shortable and Non-Shortable Stock Returns Following Earnings Announcements

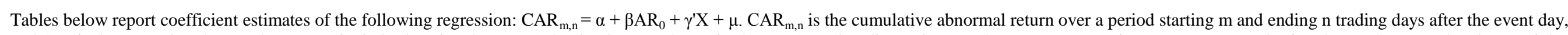

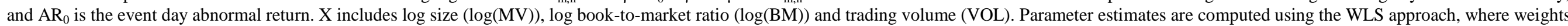
are set each cross-section has equal weight. T-statistics (Italic) are calculated using clustered standard errors.

A: Determinants of shortable stocks returns following negative earnings announcements

\begin{tabular}{|c|c|c|c|c|c|c|}
\hline \multicolumn{7}{|c|}{ Shortable \& Negative Earnings Announcements } \\
\hline & Intercept & $\mathrm{AR}_{0}$ & $\log (\mathrm{MV})$ & $\log (\mathrm{BM})$ & VOL & $\mathrm{R}^{2}$ \\
\hline \multirow[t]{2}{*}{$\mathrm{CAR}_{1,1}$} & 0.0243 & 0.0790 & -0.0028 & -0.0027 & -0.2653 & $1.22 \%$ \\
\hline & 1.15 & 0.66 & -1.41 & -0.72 & -1.50 & \\
\hline \multirow[t]{2}{*}{$\mathrm{CAR}_{1,5}$} & 0.0654 & 0.1720 & -0.0053 & 0.0024 & -0.7706 & $2.65 \%$ \\
\hline & 1.77 & 0.92 & -1.53 & 0.41 & -1.68 & \\
\hline \multirow[t]{2}{*}{$\mathrm{CAR}_{1,10}$} & 0.0614 & 0.1324 & -0.0056 & 0.0056 & -0.6795 & $1.58 \%$ \\
\hline & 1.35 & 0.54 & -1.28 & 0.66 & -1.67 & \\
\hline \multirow[t]{2}{*}{$\mathrm{CAR}_{1,20}$} & 0.1572 & 0.4311 & -0.0150 & 0.0047 & 0.2536 & $2.42 \%$ \\
\hline & 1.85 & 1.22 & -1.71 & 0.27 & 0.32 & \\
\hline \multirow{2}{*}{$\mathrm{CAR}_{1,30}$} & 0.1728 & 0.5127 & -0.0162 & 0.0110 & -0.1783 & $2.57 \%$ \\
\hline & 1.83 & 1.33 & -1.63 & 0.54 & -0.22 & \\
\hline \multirow[t]{2}{*}{$\mathrm{CAR}_{1,40}$} & 0.1952 & 0.5042 & -0.0169 & 0.0382 & -0.8628 & $5.31 \%$ \\
\hline & 2.08 & 1.24 & -1.78 & 2.01 & -0.87 & \\
\hline \multirow[t]{2}{*}{$\mathrm{CAR}_{1,50}$} & 0.2407 & 0.5778 & -0.0208 & 0.0544 & -0.7761 & $7.89 \%$ \\
\hline & 2.29 & 1.45 & -1.89 & 2.40 & -0.83 & \\
\hline \multirow[t]{2}{*}{$\mathrm{CAR}_{1,60}$} & 0.3044 & 0.6752 & -0.0277 & 0.0598 & -0.2628 & $7.52 \%$ \\
\hline & 2.32 & 1.52 & -1.99 & 2.20 & -0.23 & \\
\hline
\end{tabular}


B: Determinants of shortable stocks returns following positive earnings announcements

\begin{tabular}{|c|c|c|c|c|c|c|}
\hline \multicolumn{7}{|c|}{ Shortable \& Positive Earnings Announcements } \\
\hline & Intercept & $\mathrm{AR}_{0}$ & $\log (\mathrm{MV})$ & $\log (\mathrm{BM})$ & VOL & $\mathrm{R}^{2}$ \\
\hline \multirow{2}{*}{$\mathrm{CAR}_{1,1}$} & -0.0010 & -0.1338 & 0.0019 & 0.0002 & -0.1938 & $2.99 \%$ \\
\hline & -0.04 & -1.47 & 0.82 & 0.03 & -0.92 & \\
\hline \multirow{2}{*}{$\mathrm{CAR}_{1,5}$} & 0.0377 & -0.2181 & -0.0016 & -0.0027 & 0.0109 & $0.92 \%$ \\
\hline & 0.63 & -0.94 & -0.28 & -0.22 & 0.47 & \\
\hline \multirow{2}{*}{$\mathrm{CAR}_{1,10}$} & 0.0103 & -0.0916 & 0.0016 & 0.0154 & -0.0690 & $0.84 \%$ \\
\hline & 0.14 & -0.30 & 0.23 & 1.08 & -0.05 & \\
\hline \multirow[t]{2}{*}{$\mathrm{CAR}_{1,20}$} & 0.0604 & -0.1415 & -0.0036 & 0.0389 & -0.0307 & $4.24 \%$ \\
\hline & 0.79 & -0.54 & -0.49 & 2.36 & -0.03 & \\
\hline \multirow[t]{2}{*}{$\mathrm{CAR}_{1,30}$} & 0.0741 & -0.0641 & -0.0033 & 0.0465 & -1.5451 & $5.07 \%$ \\
\hline & 0.65 & -0.19 & -0.28 & 1.85 & -1.36 & \\
\hline \multirow[t]{2}{*}{$\mathrm{CAR}_{1,40}$} & 0.0601 & -0.1878 & 0.0011 & 0.0845 & 2.0258 & $11.00 \%$ \\
\hline & 0.57 & -0.57 & 0.11 & 3.36 & -1.26 & \\
\hline \multirow{2}{*}{$\mathrm{CAR}_{1,50}$} & 0.1526 & -0.0220 & -0.0103 & 0.1017 & -2.4037 & $14.77 \%$ \\
\hline & 1.27 & -0.05 & -0.85 & 3.71 & -1.15 & \\
\hline \multirow[t]{2}{*}{$\mathrm{CAR}_{1,60}$} & 0.1783 & -0.0589 & -0.0146 & 0.1110 & -1.8759 & $15.02 \%$ \\
\hline & 1.39 & -0.12 & -1.17 & 3.80 & -0.97 & \\
\hline
\end{tabular}




\begin{tabular}{|c|c|c|c|c|c|c|}
\hline & Intercept & $\mathrm{AR}_{0}$ & $\log (\mathrm{MV})$ & $\log (\mathrm{BM})$ & VOL & $\mathrm{R}^{2}$ \\
\hline \multirow[t]{2}{*}{$\mathrm{CAR}_{1,1}$} & 0.0241 & -0.1477 & -0.0059 & 0.0046 & -0.2004 & $2.90 \%$ \\
\hline & 1.46 & $-2.62 * * *$ & -2.13 & 1.91 & -1.82 & \\
\hline \multirow{2}{*}{$\mathrm{CAR}_{1,5}$} & 0.0677 & -0.1761 & -0.0146 & 0.0075 & -0.2466 & $3.10 \%$ \\
\hline & 2.55 & $-1.92 *$ & -3.29 & 1.74 & -1.87 & \\
\hline \multirow[t]{2}{*}{$\mathrm{CAR}_{1,10}$} & 0.1060 & -0.1931 & -0.0228 & 0.0088 & -0.1120 & $3.29 \%$ \\
\hline & 3.10 & $-1.65 *$ & -3.91 & 1.38 & -0.34 & \\
\hline \multirow[t]{2}{*}{$\mathrm{CAR}_{1,20}$} & 0.2157 & -0.1444 & -0.0428 & 0.0266 & -0.2786 & $6.62 \%$ \\
\hline & 4.22 & -1.02 & -4.81 & 3.16 & -1.06 & \\
\hline \multirow[t]{2}{*}{$\mathrm{CAR}_{1,30}$} & 0.3018 & -0.1990 & -0.0598 & 0.0499 & -0.3296 & $10.78 \%$ \\
\hline & 5.20 & -1.20 & -6.05 & 3.45 & -1.12 & \\
\hline \multirow[t]{2}{*}{$\mathrm{CAR}_{1,40}$} & 0.3886 & -0.2764 & -0.0779 & 0.0748 & -0.5322 & $15.30 \%$ \\
\hline & 5.89 & -1.56 & -7.01 & 4.94 & -1.80 & \\
\hline \multirow[t]{2}{*}{$\mathrm{CAR}_{1,50}$} & 0.4531 & -0.1198 & -0.0863 & 0.0968 & -0.6826 & $16.99 \%$ \\
\hline & 6.42 & -0.58 & -7.26 & 5.78 & -2.02 & \\
\hline \multirow[t]{2}{*}{$\mathrm{CAR}_{1,60}$} & 0.5686 & 0.0402 & -0.1050 & 0.1158 & -0.6483 & $18.28 \%$ \\
\hline & 6.99 & 0.18 & -7.68 & 5.80 & -0.99 & \\
\hline
\end{tabular}


D: Determinants of non-shortable stocks returns following positive earnings announcements

\begin{tabular}{|c|c|c|c|c|c|c|}
\hline \multicolumn{7}{|c|}{ Nonshortable \& Positive Earnings Announcements } \\
\hline & Intercept & $\mathrm{AR}_{0}$ & $\log (\mathrm{MV})$ & $\log (\mathrm{BM})$ & VOL & $\mathrm{R}^{2}$ \\
\hline \multirow[t]{2}{*}{$\mathrm{CAR}_{1,1}$} & 0.0071 & 0.0778 & -0.0039 & -0.0013 & 0.0182 & $1.07 \%$ \\
\hline & 0.29 & 0.92 & -1.12 & -0.49 & 0.14 & \\
\hline \multirow[t]{2}{*}{$\mathrm{CAR}_{1,5}$} & 0.0395 & -0.0155 & -0.0108 & -0.0021 & 0.1955 & $0.62 \%$ \\
\hline & 1.01 & -0.20 & -1.66 & -0.32 & 0.64 & \\
\hline \multirow[t]{2}{*}{$\mathrm{CAR}_{1,10}$} & 0.0876 & -0.1478 & -0.0170 & 0.0035 & 0.5124 & $1.73 \%$ \\
\hline & 1.63 & -1.54 & -1.88 & 0.46 & 1.51 & \\
\hline \multirow[t]{2}{*}{$\mathrm{CAR}_{1,20}$} & 0.2061 & -0.2770 & -0.0358 & 0.0077 & 0.4239 & $2.90 \%$ \\
\hline & 3.02 & -1.21 & -3.02 & 0.75 & 0.96 & \\
\hline \multirow{2}{*}{$\mathrm{CAR}_{1,30}$} & 0.2598 & -0.2331 & -0.0424 & 0.0148 & 0.2423 & $2.38 \%$ \\
\hline & 3.45 & -1.75 & -3.04 & 1.25 & 0.48 & \\
\hline \multirow[t]{2}{*}{$\mathrm{CAR}_{1,40}$} & 0.3535 & -0.1676 & -0.0591 & 0.0325 & 0.2094 & $4.14 \%$ \\
\hline & 4.17 & -1.21 & -3.76 & 2.51 & 0.38 & \\
\hline \multirow[t]{2}{*}{$\mathrm{CAR}_{1,50}$} & 0.4927 & -0.1049 & -0.0846 & 0.0404 & 0.1098 & $5.86 \%$ \\
\hline & 4.87 & -0.65 & -4.57 & 2.67 & 0.23 & \\
\hline \multirow[t]{2}{*}{$\mathrm{CAR}_{1,60}$} & 0.6264 & -0.2067 & -0.1084 & 0.0382 & 0.0534 & $6.92 \%$ \\
\hline & 5.84 & -1.23 & -5.48 & 2.28 & 0.10 & \\
\hline
\end{tabular}


Table 5. Speed of Price Adjustment for Non-Shortable Stocks Following Negative Earnings Announcements

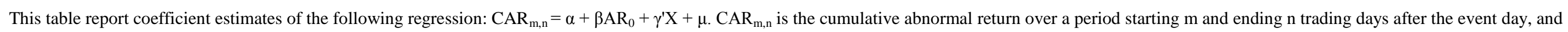

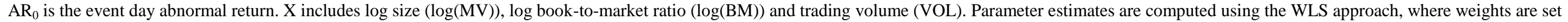
each cross-section has equal weight. T-statistics (Italic) are calculated using clustered standard errors.

\begin{tabular}{|c|c|c|c|c|c|}
\hline \multicolumn{6}{|c|}{ Nonshortable \& Negative Earnings Announcements } \\
\hline & Intercept & $\mathrm{AR}_{0}$ & $\log (\mathrm{MV})$ & $\log (\mathrm{BM})$ & VOL \\
\hline \multirow[t]{2}{*}{$\mathrm{CAR}_{1,1}$} & 0.0241 & -0.1477 & -0.0059 & 0.0046 & -0.2004 \\
\hline & 1.46 & $-2.62 * * *$ & -2.13 & 1.91 & -1.82 \\
\hline \multirow[t]{2}{*}{$\mathrm{CAR}_{1,2}$} & 0.0092 & -0.1711 & -0.0035 & 0.0041 & -0.1603 \\
\hline & 0.45 & $-2.50 * *$ & -1.02 & 1.32 & -2.01 \\
\hline \multirow[t]{2}{*}{$\mathrm{CAR}_{1,3}$} & 0.0375 & -0.1812 & -0.0086 & 0.0055 & -0.2676 \\
\hline & 1.62 & $-2.56 * *$ & -2.25 & 1.62 & -2.08 \\
\hline \multirow[t]{2}{*}{$\mathrm{CAR}_{1,4}$} & 0.0426 & -0.181 & -0.0096 & 0.0069 & -0.4056 \\
\hline & 1.66 & $-2.16^{* *}$ & -2.26 & 1.69 & -2.18 \\
\hline \multirow[t]{2}{*}{$\mathrm{CAR}_{1,5}$} & 0.0677 & -0.1761 & -0.0146 & 0.0075 & -0.2466 \\
\hline & 2.55 & $-1.92 *$ & -3.29 & 1.74 & -1.87 \\
\hline \multirow[t]{2}{*}{$\mathrm{CAR}_{1,6}$} & 0.0528 & -0.2633 & -0.0135 & 0.0075 & -0.3782 \\
\hline & 1.75 & $-2.43 * *$ & -2.73 & 1.49 & -2.61 \\
\hline \multirow{2}{*}{$\mathrm{CAR}_{1,7}$} & 0.0693 & -0.219 & -0.0158 & 0.0074 & -0.3847 \\
\hline & 2.22 & $-1.93 *$ & -3.1 & 1.53 & -2.45 \\
\hline \multirow[t]{2}{*}{$\mathrm{CAR}_{1,8}$} & 0.0883 & -0.252 & -0.0201 & 0.008 & -0.5414 \\
\hline & 2.65 & $-2.17 * *$ & -3.59 & 1.47 & -3.11 \\
\hline \multirow[t]{2}{*}{$\mathrm{CAR}_{1,9}$} & 0.0974 & -0.21 & -0.0213 & 0.008 & -0.1938 \\
\hline & 2.97 & $-1.74 *$ & -3.82 & 1.35 & -0.53 \\
\hline \multirow[t]{2}{*}{$\mathrm{CAR}_{1,10}$} & 0.106 & -0.1931 & -0.0228 & 0.0088 & -0.112 \\
\hline & 3.1 & -1.56 & -3.91 & 1.38 & -0.34 \\
\hline \multirow[t]{2}{*}{$\mathrm{CAR}_{1,11}$} & 0.1088 & -0.1724 & -0.023 & 0.0105 & -0.221 \\
\hline & 3.23 & -1.51 & -4.04 & 1.72 & -0.74 \\
\hline \multirow[t]{2}{*}{$\mathrm{CAR}_{1,12}$} & 0.1286 & -0.1437 & -0.0259 & 0.0119 & -0.2966 \\
\hline & 3.73 & -1.22 & -4.47 & 1.98 & -1.05 \\
\hline \multirow[t]{2}{*}{$\mathrm{CAR}_{1,13}$} & 0.136 & -0.1009 & -0.0272 & 0.0141 & -0.2392 \\
\hline & 3.7 & -0.81 & -4.33 & 2.15 & -0.73 \\
\hline \multirow[t]{2}{*}{$\mathrm{CAR}_{1,14}$} & 0.1861 & -0.0546 & -0.0357 & 0.0131 & -0.1611 \\
\hline & 4.5 & -0.43 & -4.91 & 1.76 & -0.52 \\
\hline \multirow[t]{2}{*}{$\mathrm{CAR}_{1,15}$} & 0.2085 & -0.0339 & -0.0393 & 0.0151 & -0.1946 \\
\hline & 4.76 & -0.27 & -5.15 & 1.9 & -0.67 \\
\hline
\end{tabular}

